\title{
Locus of Control and its Relationship with Mental Health among College Students
}

\author{
Sangeeta Sidola*, Sarita Saini and Tejpreet K. Kang
}

Department of Human Development and Family Studies, College of Community Science, Punjab Agricultural University, Ludhiana, Punjab, India

*Corresponding author

\begin{tabular}{|l|}
\hline Ke $\mathbf{y}$ w o r d $\mathbf{s}$ \\
$\begin{array}{l}\text { Locus of control, } \\
\text { mental health, } \\
\text { internal locus of } \\
\text { control, external } \\
\text { locus of control }\end{array}$ \\
\hline Article Info \\
\hline $\begin{array}{l}\text { Accepted: } \\
\text { 15 December } 2019 \\
\text { Available Online: } \\
\text { 20 January } 2020\end{array}$
\end{tabular}

\section{A B S T R A C T}

\section{Introduction}

Locus of Control (LOC) is understood as a belief about whether the outcomes of particular action are contingent on what one does (internal control orientation) or an event outside ones personal control (external control orientation). The internals believes that hard work and individual capabilities lead to constructive results (Carrim et al., 2006) or enduring individuality (Littunen \& Storhammar 2000). Hence, the reinforcement an individual receives from his environment is a consequence of his own actions and hard works (Lee-Kelley 2006). This notion strengthens the faith that their fate is in their 
hand and they are master of their own destiny (Boone et al., 2005).

However, many researchers reported that the individuals with external control orientation live with a conviction that outcomes of their own actions are dependent on the cause beyond their personal control (Landy \& Contre 2004; Martin et al., 2005). The behaviours and their outcomes are directed randomly, and are believed to be managed by the external forces. The external locus of control is usually differentiated into different external controls: control by chance or luck and control by powerful others (Levenson 1973). People with external locus of control are unwilling to alter their behaviour as they have less trust in all the basic sources for changing reinforcements (Marks 1998). Even though, in the case of favourable outcome, the credit may not be taken personally, but dedicated to the fate, easiness of the task or on a cooperative support by a powerful other (Hyatt \& Prawitt 2001).

Ample research studies have been undertaken to comprehend LOC as a correlate of multiple significant socio-personal attributes. The person's mental health is also one of them. Health is an indispensable quality in human beings. A healthy individual is not only physically healthy, but is also mentally healthy (Kaur \& Arora 2014). The modern day perception of health not only includes optimum functioning of the body but also takes into account the sound, skillful mind as well as balanced emotions. Parameshvara (2010) defines mental health as a state of perfect, including not simply the deficiency of ailments or turmoil but also existence of various factors such as life satisfaction, selfesteem and sociability. According to World Health Organization (2001), mental health is a state of well-being through which each and every person understands his or her own capabilities, develops coping strategies to deal with common stresses of life, offer his or her contribution to community, and is able to work efficiently and productively.

Locus of control is a very important factor while performing any tasks as it affects the moods as well as impact individuals in diverse areas of their lives (Lefcourt 1976). A plethora of available researches also project the relationship between varying levels of personality orientation and mental health of the individuals (Karayurt \& Dicle 2008; Armstrong \& Boothroyd 2008). Shojae and French (2014) pioneered a study to explore the association between LOC and mental health of the respondents. The study revealed that there was a close significant association between locus of control and mental health of young adults. The individuals with internal locus of control were found to possess high level of mental health and were emotionally stable and had a balance between different aspects of life whereas those having external locus of control had comparatively lower level of mental wellbeing with more pessimistic attitude towards life. So, in light of the foregoing discussion the present study was undertaken with the following objectives:

The main objectives of this study includes, to examine the locus of control and mental health of the college students. And to delineate impact of locus of control on mental health of the college students.

\section{Materials and Methods}

\section{Sample selection}

The study was conducted on the undergraduate students studying in the four constituent colleges [viz. College of Agriculture (COA), College of Basic Sciences and Humanities (COBS\&H), College of Agricultural Engineering and Technology (COAE\&T) and College of Community 
Science (COCS)] of Punjab Agricultural University, Ludhiana, Punjab. A sample of 200 male and 200 female students studying in different undergraduate programmes was selected through proportionate sampling technique.

\section{Research instruments}

Self-structured Locus of Control Questionnaire

Self-structured Locus of Control Questionnaire adapted from Rotter's Locus of Control Scale (1966) and Levenson's Multidimensional Scale adapted by Vohra (1992) was used to assess the locus of control of the selected students.

\section{Mental Health Battery (MHB)}

Mental Health Battery (MHB) developed by Singh and Gupta (2000) was modified and employed to assess the mental health of the sample subjects. The battery was designed to measure the status of mental health of the respondents in selected indices viz. Emotional Stability (ES), Over-all Adjustment (OA), Autonomy (A) and Security- Insecurity (SI). The desirable 85 items from the battery were taken for the present study.

\section{Statistical analysis of data}

Frequencies, percentages, ANOVA, correlation analysis were used for statistical analysis of the data.

\section{Results and Discussion}

\section{Status of Locus of Control among College Students}

The data presented in the Table 1 reveals the college-wise mean scores $( \pm \mathrm{SD})$ of respondents and the interpretation of the data elucidates statistically significant differences in both internal as well as external locus of control $(\mathrm{F}=12.53 ; \mathrm{p}<0.01 \& \mathrm{~F}=44.56$; $\mathrm{p}<0.01$, respectively) across varying colleges.

However, in internal locus of control, the mean scores $( \pm \mathrm{SD})$ of the respondents from different colleges were at par except for the College of Agricultural Engineering and Technology where mean scores of respondents were found to be the highest amongst all. This suggests that the respondents in this college were likely to be more industrious and focused.

Further, the data relating to external locus of control divulged that respondents from College of Agriculture (87.5 \pm 25.6$)$ and College of Community Science (85.5 \pm 5.1$)$ had better mean scores $( \pm \mathrm{SD})$ than respondents from College of Agricultural Engineering \& Technology $(72.0 .1 \pm 19.5)$ as well as College of Basic Sciences and Humanities (59.3.1 \pm 9.6$)$. This is suggestive that respondents from College of Agriculture and College of Community Science were likely to be more oriented towards factors like luck, fate and powerful others.

\section{Assessment of Mental Health of College Students across varying Dimensions and Levels of Mental Health}

The data presented in the Table 2 depicts the college-wise distribution of students across varying dimensions and levels of mental health. The in-depth analysis of the data is represented under the following sub-heads:

\section{'Emotional stability' as a dimension of mental health}

The data presented regarding 'emotional stability' dimension of mental health divulged that a major proportion of the respondents (68.80\%) from College of Agriculture were at 
medium level of emotional stability followed by 30.40 per cent at high and a negligible proportion $(0.80 \%)$ at low level of emotional stability dimension of mental health.

A similar trend was noticed for College of Basic Sciences and Humanities where majority of the respondents $(88.57 \%)$ were at medium level of emotional stability followed by 10.48 per cent at high and a negligible $(0.95 \%)$ number of respondents at low level of emotional stability dimension of mental health.

However, a slightly different picture was seen in College of Agricultural Engineering and Technology where the majority of the respondents $(88.89 \%)$ were at medium level of emotional stability followed by 6.94 per cent at low and 4.17 per cent at high level of emotional stability dimension of mental health.

Similarly, in College of Community Science the results revealed that the majority of the respondents $(88.46 \%)$ were at medium level of emotional stability followed by 7.69 per cent at low and remaining 3.85 per cent at high level of emotional stability dimension of mental health.

Furthermore, irrespective of the colleges the overall data explicates that the majority of the respondents $(82.50 \%)$ were at medium level of emotional stability followed by 14 per cent at high and rest 3.50 per cent at low level of emotional stability dimension of mental health.

Thus, it could be inferred from the foregoing analysis that the majority of the respondents with medium level were likely to have an average capacity of maintaining their emotional balance under stressful circumstances and were moderately open to criticism.
'Over-all adjustment' as a dimension of mental health

The data further discloses the distribution of respondents as per 'over-all adjustment' dimension of mental health. The data suggests that a major proportion of the respondents $(61.60 \%)$ from the College of Agriculture were at medium level of over-all adjustment followed by 37.60 per cent at high level and only 0.80 per cent at low level of over-all adjustment dimension of mental health. Similarly, the data for College of Basic Sciences and Humanities exhibits that the majority of the respondents were at medium level $(83.81 \%)$ followed by 13.33 per cent at high and 2.86 per cent at low level of 'over-all adjustment' dimension of mental health. The further analysis of data displayed a similar picture for College of Agricultural Engineering and Technology as well where also a major proportion of the respondents $(76.39 \%)$ were at medium level of over-all adjustment followed by 22.92 per cent at high and negligible number of respondents $(0.69 \%)$ at low level of over-all adjustment dimension of mental health.

A similar trend was also noticed for College of Community Science where a substantial number of respondents $(65.38 \%)$ were at medium level of overall adjustment followed by 30.77 per cent at high and only 3.85 per cent at low level of over-all adjustment dimension of mental health.

However, the overall data irrespective of the colleges indicated that a major proportion of the respondents $(73.00 \%)$ were at medium level of over-all adjustment followed by more than one-fourth at high $(25.50 \%)$ and remaining 1.50 per cent at low level of overall adjustment dimension of mental health.

Hence, it can be concluded that the majority of the respondents had an average level of over- 
all adjustment and thus were likely to be moderately amicable, sincere, friendly and moderately work oriented.

\section{'Autonomy' as a dimension of mental health}

The further probe into the data illustrates 'autonomy' dimension of mental health. The data explains that more than half of the respondents $(60.00 \%)$ from College of Agriculture were at medium level of autonomy followed by 38.40 per cent at high and only 1.60 per cent at low level of autonomy dimension of mental health.

Further, majority of the respondents (94.29\%) from College of Basic Sciences and Humanities were at medium level of autonomy and rest at high (4.76\%) and a negligible number of respondents $(0.95 \%)$ at low level of autonomy dimension of mental health. A similar trend was reported for College of Agricultural Engineering and Technology where the majority of respondents were at medium (90.97\%) level of autonomy and remaining 9.03 per cent at high level of autonomy dimension of mental health.

College of Community Science also depicted the similar trend where the majority of the respondents were at medium $(88.46 \%)$ and remaining 11.54 per cent at high level of autonomy dimension of mental health.

However, the overall data irrespective of colleges portrayed that the majority of the respondents were at medium level $(82.00 \%)$ followed by 17.25 per cent at high and only 0.75 per cent at low level of autonomy dimension of mental health. Hence, the results suggests that the majority of the respondents being at medium level of autonomy could be presumed to have an average ability to stand up with the truth and obedience as well as had average aspirations for goal achievement.
'Security-Insecurity' as a dimension of mental health

The inspection of data further unveils the 'security-insecurity' dimension of mental health. The data ascertained that the majority of the respondents from all the four constituent colleges viz. College of Agriculture, College of Basic Sciences and Humanities, College of Agricultural Engineering and Technology and College of Community Science were at medium level of security-insecurity $(64.80 \%, 93.33 \%, 88.89 \%$ \& $92.31 \%$, respectively) dimension of mental health. However, the overall data irrespective of the colleges revealed that the majority of the respondents were clustered at medium level of mental health $(82.75 \%)$ followed by 15.25 per cent at high and only 2 per cent at low level of security-insecurity dimension of mental health. This indicates that the majority of the respondents presumably had an average sense of safety, confidence, moderately able to handle the adverse situation.

\section{'Overall mental health' of the respondents}

The data pertaining to 'overall mental health' of the respondents depicted that more than half of the respondents (54.40\%) from College of Agriculture were at medium level of mental health as well as a substantial number of respondents $(45.60 \%)$ were at high level of overall mental health.

Furthermore, in College of Basic Sciences and Humanities as well as College of Agricultural Engineering and Technology majority of the respondents $(91.43 \%$ \& $93.06 \%$, respectively) were at medium level and rest were at high level $(8.57 \% \& 6.94 \%$, respectively) of overall mental health. Similarly, majority of the respondents from College of Community Science were at medium $(88.46 \%)$ level of mental health and rest at high (11.54\%) level of overall mental health. 
Table.1 College-wise mean score $( \pm \mathrm{SD})$ differences across varying types of locus of control among students

\begin{tabular}{|c|c|c|c|c|c|c|}
\hline \multirow{3}{*}{$\begin{array}{l}\text { Types of } \\
\text { Locus of } \\
\text { Control }\end{array}$} & \multicolumn{6}{|c|}{ Constituent Colleges } \\
\hline & $\underset{\left(n_{1}=125\right)}{\text { COA }}$ & $\begin{array}{c}\text { COBS\&H } \\
\left(\mathrm{n}_{2}=105\right)\end{array}$ & $\begin{array}{c}\text { COAE\&T } \\
\left(n_{3}=144\right)\end{array}$ & $\begin{array}{c}\text { COCS } \\
\left(n_{4}=26\right)\end{array}$ & $\begin{array}{l}\text { Overall } \\
\text { sample } \\
(n=400)\end{array}$ & F-value \\
\hline & Mean \pm SD & Mean \pm SD & Mean \pm SD & Mean \pm SD & Mean \pm SD & \\
\hline Internal & $86.6^{\mathrm{a}} \pm 27.7$ & $93.1^{\mathrm{a}} \pm 29.0$ & $104.7^{\mathrm{b}} \pm 20.8$ & $90.1^{\mathrm{a}} \pm 9.8$ & $95.0 \pm 26$ & $12.53 * *$ \\
\hline External & $87.5^{c} \pm 25.6$ & $59.3^{\mathrm{a}} \pm 9.6$ & $72.0^{b} \pm 19.5$ & $85.5^{\mathrm{c}} \pm 5.1$ & $174.4 \pm 22.1$ & $44.56^{* *}$ \\
\hline
\end{tabular}

Table.2 College-wise per cent distribution of students across varying dimensions and levels of mental health

\begin{tabular}{|c|c|c|c|c|c|c|}
\hline \multirow{3}{*}{$\begin{array}{c}\text { Dimensions } \\
\text { of } \\
\text { Mental } \\
\text { Health }\end{array}$} & \multirow{3}{*}{$\begin{array}{l}\begin{array}{c}\text { Levels } \\
\text { of } \\
\text { Mental } \\
\text { Health }\end{array} \\
\end{array}$} & \multicolumn{5}{|c|}{ Constituent Colleges } \\
\hline & & $\begin{array}{c}\text { COA } \\
\left(\mathrm{n}_{1}=125\right)\end{array}$ & $\begin{array}{c}\text { COBS\&H } \\
\left(n_{2}=105\right)\end{array}$ & $\begin{array}{c}\text { COAE\&T } \\
\left(n_{3}=144\right)\end{array}$ & $\begin{array}{c}\text { COCS } \\
\left(n_{4}=26\right)\end{array}$ & $\begin{array}{l}\text { Overall } \\
\text { Sample } \\
(n=400)\end{array}$ \\
\hline & & $f(\%)$ & $f(\%)$ & $f(\%)$ & $f(\%)$ & $f(\%)$ \\
\hline \multirow{3}{*}{$\begin{array}{l}\text { Emotional } \\
\text { Stability }\end{array}$} & High & $38(30.40$ & $11(10.48)$ & $6(4.17)$ & $1(3.85)$ & $56(14.00)$ \\
\hline & Medium & $86(68.80)$ & 93(88.57) & $128(88.89)$ & $23(88.46)$ & $330(82.50)$ \\
\hline & Low & $1(0.80)$ & $1(0.95)$ & 10(6.94) & 2(7.69) & $14(3.50)$ \\
\hline \multirow{3}{*}{$\begin{array}{c}\text { Over -all } \\
\text { adjustment }\end{array}$} & High & $47(37.60)$ & 14(13.33) & $33(22.92)$ & $8(30.77)$ & $102(25.50)$ \\
\hline & Medium & $77(61.60)$ & $88(83.81)$ & 110(76.39) & $17(65.38)$ & $292(73.00)$ \\
\hline & Low & $1(0.80)$ & $3(2.86)$ & 1(0.69) & $1(3.85)$ & $6(1.50)$ \\
\hline \multirow[t]{3}{*}{ Autonomy } & High & $48(38.40)$ & $5(4.76)$ & 13(9.03) & $3(11.54)$ & $69(17.25)$ \\
\hline & Medium & $75(60.00)$ & 99(94.29) & 131(90.97) & $23(88.46)$ & $328(82.00)$ \\
\hline & Low & $2(1.60)$ & $1(0.95)$ & $0(0.00)$ & $0(0.00)$ & $3(0.75)$ \\
\hline \multirow{3}{*}{$\begin{array}{l}\text { Security- } \\
\text { Insecurity }\end{array}$} & High & $44(35.20)$ & $6(5.71)$ & $10(6.94)$ & $1(3.85)$ & $61(15.25)$ \\
\hline & Medium & $81(64.80)$ & 98(93.33) & $128(88.89)$ & $24(92.31)$ & $331(82.75)$ \\
\hline & Low & $0(0.00)$ & $1(0.95)$ & $6(4.17)$ & $1(3.85)$ & $8(2.00)$ \\
\hline \multirow{3}{*}{$\begin{array}{l}\text { Overall } \\
\text { Mental } \\
\text { Health }\end{array}$} & High & $57(45.60)$ & $9(8.57)$ & $10(6.94)$ & $3(11.54)$ & $79(19.75)$ \\
\hline & Medium & $68(54.40)$ & 96(91.43) & 134(93.06) & $23(88.46)$ & $321(80.25)$ \\
\hline & Low & & & 0 & & \\
\hline
\end{tabular}

Figures in parentheses indicate percentages 
Table.3 Correlation between types of locus of control and varying dimensions of mental health of students across constituent colleges

\begin{tabular}{|c|c|c|c|c|c|c|c|c|c|c|c|c|c|c|c|}
\hline \multirow{4}{*}{$\begin{array}{c}\text { Dimensions } \\
\text { of Mental } \\
\text { Health }\end{array}$} & \multicolumn{15}{|c|}{$\begin{array}{l}\text { Types of Locus of Control } \\
(n=400)\end{array}$} \\
\hline & \multicolumn{8}{|c|}{ Internal (r) } & \multicolumn{7}{|c|}{ External (r) } \\
\hline & \multicolumn{2}{|c|}{$\begin{array}{c}\text { COA } \\
\left(n_{1}=125\right)\end{array}$} & \multicolumn{2}{|c|}{$\begin{array}{c}\text { COBS\&H } \\
\left(n_{2}=105\right)\end{array}$} & \multicolumn{2}{|c|}{$\begin{array}{c}\text { COAE\&T } \\
\left(n_{3}=144\right)\end{array}$} & \multicolumn{2}{|c|}{$\begin{array}{c}\text { COCS } \\
\left(n_{4}=26\right)\end{array}$} & \multicolumn{2}{|c|}{$\begin{array}{c}\text { COA } \\
\left(n_{1}=125\right)\end{array}$} & \multicolumn{2}{|c|}{$\begin{array}{c}\text { COBS\&H } \\
\left(\mathbf{n}_{2}=105\right)\end{array}$} & \multicolumn{2}{|c|}{$\begin{array}{c}\text { COAE\&T } \\
\left(n_{3}=144\right)\end{array}$} & \multirow{2}{*}{$\begin{array}{c}\text { COCS } \\
\left(\mathbf{n}_{4}=26\right) \\
\text { Females } \\
(\mathbf{r})\end{array}$} \\
\hline & $\begin{array}{c}\text { Males } \\
\text { (r) }\end{array}$ & $\begin{array}{c}\text { Femal } \\
\text { es } \\
(\mathbf{r})\end{array}$ & $\begin{array}{c}\text { Mal } \\
\text { es } \\
(\mathbf{r})\end{array}$ & $\begin{array}{c}\text { Femal } \\
\text { es } \\
(\mathbf{r})\end{array}$ & $\begin{array}{c}\text { Mal } \\
\text { es } \\
(\mathbf{r})\end{array}$ & $\begin{array}{c}\text { Femal } \\
\text { es } \\
(\mathbf{r})\end{array}$ & $\begin{array}{c}\text { Mal } \\
\text { es } \\
(\mathbf{r})\end{array}$ & $\begin{array}{c}\text { Femal } \\
\text { es } \\
(\mathbf{r})\end{array}$ & $\begin{array}{c}\text { Mal } \\
\text { es } \\
(\mathbf{r})\end{array}$ & $\begin{array}{c}\text { Femal } \\
\text { es } \\
(\mathbf{r})\end{array}$ & $\begin{array}{c}\text { Mal } \\
\text { es } \\
(\mathbf{r})\end{array}$ & $\begin{array}{c}\text { Femal } \\
\text { es } \\
\text { (r) }\end{array}$ & $\begin{array}{c}\text { Mal } \\
\text { es } \\
(\mathbf{r})\end{array}$ & $\begin{array}{c}\text { Femal } \\
\text { es } \\
(\mathbf{r})\end{array}$ & \\
\hline $\begin{array}{l}\text { Emotional } \\
\text { Stability }\end{array}$ & -0.23 & 0.05 & $\overline{-}-$ & 0.02 & $\begin{array}{l}0- \\
.12\end{array}$ & -0.18 & 0.40 & -0.08 & 0.16 & -0.09 & 0. & 0.16 & - & 0.05 & -0.29 \\
\hline $\begin{array}{c}\text { Over-all } \\
\text { adjustment }\end{array}$ & -0.15 & 0.008 & $\begin{array}{c}- \\
0.16\end{array}$ & -0.01 & 0.12 & 0.15 & $-\overline{2}$ & 0.08 & 0.21 & -0.14 & $\begin{array}{c}- \\
0.19\end{array}$ & -0.06 & $\begin{array}{c}- \\
0.11\end{array}$ & -0.21 & -0.19 \\
\hline Autonomy & $-0.31 *$ & -0.17 & $\begin{array}{c}- \\
0.10 \\
\end{array}$ & -0.02 & 0.03 & 0.03 & 0.19 & -0.16 & 0.23 & 0.00 & $\begin{array}{c}- \\
0.06 \\
\end{array}$ & -0.04 & 0.00 & -0.18 & -0.33 \\
\hline $\begin{array}{l}\text { Security- } \\
\text { Insecurity }\end{array}$ & -0.05 & 0.11 & $\begin{array}{c}- \\
0.05\end{array}$ & 0.16 & 0.05 & 0.11 & 0.54 & -0.11 & 0.24 & -0.11 & $\begin{array}{c}- \\
0.11\end{array}$ & $-0.35^{*}$ & 0.12 & $\begin{array}{l}- \\
0.38 * \\
*\end{array}$ & -0.28 \\
\hline $\begin{array}{c}\text { Overall } \\
\text { mental } \\
\text { health }\end{array}$ & -0.01 & 0.12 & 0.22 & 0.15 & 0.04 & 0.08 & 0.21 & 0.12 & 0.15 & 0.10 & 0.18 & 0.14 & $\begin{array}{c}0.44 \\
* *\end{array}$ & 0.14 & 0.12 \\
\hline
\end{tabular}

$\mathrm{r}=$ correlation coefficient

$* p<0.05, * * p<0.01$ 
Table.4 Regression analysis of types of locus of control on varying dimensions of mental health of students

\begin{tabular}{|c|c|c|c|c|c|c|}
\hline & & & & & \multicolumn{2}{|c|}{$(n=400)$} \\
\hline $\begin{array}{l}\text { Dimensions of } \\
\text { Mental Health }\end{array}$ & $\begin{array}{l}\text { Types of } \\
\text { Locus of } \\
\text { Control }\end{array}$ & $\begin{array}{c}\text { Regression } \\
\text { Coefficient }(\beta)\end{array}$ & $\begin{array}{l}\text { Standard } \\
\text { Error }\end{array}$ & $\begin{array}{l}\text { Constant } \\
(\alpha)\end{array}$ & $\mathbf{R}^{2}$ & t-value \\
\hline \multirow{2}{*}{$\begin{array}{l}\text { Emotional } \\
\text { Stability }\end{array}$} & Internal & 0.006 & 0.006 & \multirow[t]{2}{*}{9.205} & \multirow[t]{2}{*}{0.003} & 1.029 \\
\hline & External & 0.006 & 0.007 & & & 0.801 \\
\hline \multirow{2}{*}{$\begin{array}{c}\text { Over-all } \\
\text { adjustment }\end{array}$} & Internal & 0.034 & 0.015 & \multirow[t]{2}{*}{20.251} & \multirow[t]{2}{*}{$0.04 * *$} & $2.30 *$ \\
\hline & External & -0.013 & 0.017 & & & 0.75 \\
\hline \multirow[t]{2}{*}{ Autonomy } & Internal & 0.010 & 0.005 & 6.752 & 0.00 & 1.78 \\
\hline & External & 0.011 & 0.006 & & & 1.71 \\
\hline \multirow{2}{*}{$\begin{array}{l}\text { Security- } \\
\text { Insecurity }\end{array}$} & Internal & 0.012 & 0.006 & \multirow[t]{2}{*}{6.775} & \multirow[t]{2}{*}{0.01} & 2.10 \\
\hline & External & 0.006 & 0.007 & & & 0.92 \\
\hline \multirow{2}{*}{$\begin{array}{l}\text { Overall Mental } \\
\text { Health }\end{array}$} & Internal & 0.050 & 0.025 & \multirow[t]{2}{*}{42.982} & \multirow[t]{2}{*}{$0.02 * *$} & $1.976 *$ \\
\hline & External & 0.002 & 0.030 & & & 0.25 \\
\hline
\end{tabular}

However, irrespective of the colleges, the overall data of the respondents explicates that the majority of the respondents $(80.25 \%)$ were at medium level of overall mental health and rest 19.75 per cent at high level of overall mental health. However, it is clearly evident from the data that none of the respondent from the four constituent colleges fell in the category of low level of overall mental health. Thus, from the foregoing in-depth analysis of the data it can be concluded that irrespective of the colleges, the majority of the respondents had medium level of mental health which indicates that respondents were probably average in managerial skills, attitude, values as well as self-concept. Also, were likely to be average in rational choices to achieve their goals.

Correlation analysis of Locus of Control with Mental Health among College Students

The data furnished in the Table 3 illustrates the correlation between types of locus of control and varying dimensions of mental health across respondents from varying colleges. It was clearly evident from the data that in all the four constituent colleges i.e. College of Agriculture, College of Basic Sciences and Humanities, College of Agricultural Engineering and Technology as well as College of Community Science a statistically non-significant correlation existed between internal locus of control and all the dimensions of mental health (viz. emotional stability, over-all adjustment, autonomy, and security-insecurity) and overall mental health. However, for College of Agriculture a significant negative correlation was observed between internal locus of control and 'autonomy' dimension of mental health of the male respondents $(r=-0.31 ; p<0.05)$ which indicates that the males with internal control orientation were likely to be more dependent on others.

But, the data relating to external locus of control and varying dimensions of mental health revealed that across all the constituent colleges a statistically non-significant correlation existed between external locus of control and almost all the dimensions of mental health (emotional stability, over-all adjustment, autonomy, security-insecurity and overall mental health) except for College of 
Basic Sciences and Humanities where the significant negative correlation existed between external locus of control and 'security-insecurity' dimension of the female respondents $(r=-0.35 ; \mathrm{p}<0.05)$ which indicates that the female respondents who were externally motivated were more likely to be anxious and fearful in difficult situations.

Further, in College of Agricultural Engineering and Technology also a statistically significant positive correlation was noticed between external locus of control and 'overall mental health' among the male respondents $(\mathrm{r}=0.44 ; \mathrm{p}<0.01)$. This signifies that the male respondents who were externally motivated were expected to have better attitude towards themselves and others whereas a significant negative correlation existed between external locus of control and 'security-insecurity' dimension of the female respondents $(r=-0.38 ; \mathrm{p}<0.01)$ which pointed out that the female respondents with external locus of control were likely to have a feeling of unproductiveness and lack of assurance.

\section{Contribution of Locus of Control towards Mental Health of College Students}

Data contained in the Table 4 focuses on the contribution of two types of locus of control (independent variable) towards varying dimensions of mental health (dependent variable) of the students. The regression analysis of the data depicts a significant positive contribution of internal locus of control on over-all adjustment $(\mathrm{t}=2.30$; $\mathrm{p}<0.05)$ dimension as well as overall mental health $(\mathrm{t}=1.97 ; \mathrm{p}<0.05)$. The $\mathrm{R}^{2}$ indicates that internal LOC contributed 4 per cent towards over-all adjustment dimension of mental health and 2 per cent towards overall mental health. The regression coefficient $(\beta)$ indicated the positive contribution by internal locus of control on over-all adjustment dimension as well as overall mental health of the students.
Hence, it can be concluded that internal locus of control has a contributing relationship with over-all adjustment and overall mental health. However, non-significant contribution of internal locus of control was found with emotional stability, autonomy and securityinsecurity dimensions of mental health. Also, a statistically non-significant contribution of external locus of control was observed towards all the dimensions of mental health.

The overview of the foregoing results suggests that there were significant differences in LOC among students from different colleges as among respondents with internal LOC, students from COAE\&T had better mean scores whereas among those with external LOC, respondents from COA as well as COCS had superior mean scores. However, majority of the respondents with respect to their mental health were at medium level across all the dimensions as well as in overall mental health. Furthermore, a significant negative correlation was observed between internal locus of control and 'autonomy' dimension (male respondents from COA), 'security-insecurity' dimension (female respondents from COBS\&H) as well as 'security-insecurity' dimension of mental health (female respondents from COAE\&T) whereas, a statistically significant positive correlation was noticed between external locus of control and 'overall mental health' of male respondents from COAE\&T. A significant positive contribution of internal locus of control was also observed on over-all adjustment dimension and overall mental health of the respondents.

Thus, the results point out that the individuals with internal locus of control displayed better mental health and were likely to be more independent, believing in themselves and not letting the external forces influence them. Moreover, internals are acknowledged to have a thought process that plays a very crucial role 
in affecting the events which has an impact on their lives. The findings of the study are supported by Jain and Singh (2015) who reported that individuals who had an inner LOC displayed high level of mental health and overall better adjustment pattern which includes social, emotional, home, educational domains and health adjustment domain than the individuals who had outer locus of control. Thus, administrators, healthcare providers, and educators can play an important role in developing protective mental health programmes through appropriate LOC to build an encouraging educational setting so as to promote students' psychosocial well-being, enhance their efficiency, boost their achievement, save their souls and wealth, as well as shield families and communities. Consequently, more attention should be given on mental health of the students (Aldiabat et al., 2014).

\section{References}

Aldiabat, K.M., Nasir, A., Matani., and Navenec, C.L. 2014. Mental health among undergraduate university students: A background paper for administrators, educators and healthcare providers. Universal Journal of Public Health. 2(8):209-214.

Armstrong, M.I., and Boothroyd, R.A. 2008. Predictors of emotional well-being in at-risk adolescent girls: developing preventive intervention strategies. Journal of Behavioural Health Services and Research. 35(4):435.

Boone, C., Olffen, W.V., and Witteloostuijn, A.J. 2005. Team locus of control composition, leadership structure, information acquisition, and financial performance: A business simulation study. Academy of Management Journal. 48(5):889-909.

Carrim, N.M.H., Basson, J., and Coetzee, M. 2006. The relationship between job satisfaction and locus of control in a South African call centre environment. South African Journal of Labour Reations. 30(2):66-81.

Hyatt, T.A., and Prawitt, D.F. 2001. Does congruence between audit structure and auditor's locus of control affect job performance? Accounting Review. 76(2):1-7.

Jain, M., and Singh, S. 2015. Locus of control and its relationship with mental health and adjustment among adolescent females. Journal of Mental Health and Human Behaviour. 20(1):16-21.

Karayurt, O., and Dicle, A. 2008. The relationship between locus of control and mental health status among baccalaureate nursing students in Turkey. Social Behaviour and Personality: An International Journal. 36(7):919-930.

Kaur, J., and Arora, B. 2014. Study of academic achievement in relation to mental health of adolescents. International Journal of Humanities, Arts, Medicine and Sciences. 2(4):914.

Landy, F.J., and Conte, J.M. 2004. Work in the 21st century: An Introduction to Industrial \& Organizational Psychology. MA: McGraw-Hill, Boston.

Lee-Kelley. 2006. Locus of control and attitudes to working in virtual teams. International Journal of Project Management. 24(3):234-243.

Levenson, H. 1973. Multidimensional locus of control in psychiatric patients. Journal of Consulting and Clinical Psychology. 41(3):397-404.

Lefcourt, H.M. 1976. Locus of control. Lawrence Erlbaum Associates, New York. Pp 672-89.

Littunen., and Storhammar, E. 2000. The indicators of locus of control in the small business context. Journal of 
Enterprising Culture. 8(4):343-361.

Marks, L.I. 1998. Deconstructing locus of control: Implications for practitioners. Journal of Counseling and Development. 76(3):251-259.

Martin, R., Thomas, G., Charles, C., Epitropaki, O., and McNamara, R. 2005. The role of leader-member exchanges in mediating the relationship between locus of control \& work reactions. Journal of Occupational and Organizational Psychology. 78(1):141-147.

Parameshvara, D.M. 2010. Malaysia mental health country profile. International Review of Psychiatry. 16(1-2):167176.
Rotter, J.B. 1966. Generalized expectancies for internal versus external control of reinforcement. Psychological Monographs: General and Applied. 80(1):609-615.

Shojae, M., and French, C. 2014. The Relationship between mental health components and locus of control in youth. Psychology. 5:966-978.

Singh, A.K., and Gupta, A.S. 2000. Manual for Mental Health Battery. Ankur Psychological Agency, Lucknow.

World Health Organization (WHO) (2001) Mental Health: New Understanding, New Hope. World Health Organization, Geneva.

\section{How to cite this article:}

Sangeeta Sidola, Sarita Saini and Tejpreet K. Kang. 2020. Locus of Control and its Relationship with Mental Health among College Students Int.J.Curr.Microbiol.App.Sci. 9(01): 210-220. doi: https://doi.org/10.20546/ijcmas.2020.901.024 